\title{
The Constitutional and Legal Basis of the Decision-Making Processes Applied by Public Administration Bodies in the Slovak Republic
}

\section{Introduction}

Every decision-making process in public administration must result from the idea of lawful state as it is anchored in Article 1(1) of the Slovak Constitution; it means that by law the Slovak Republic is a sovereign, democratic and lawful state, not bound to any ideology or religion. Additionally, when making decisions, one is strictly required to observe the provisions of Article 2(2) of the Constitution referring to the fact that state bodies must basically act on the grounds of the Constitution, within its scope and in a way provided by law. At the same time, it means that everybody can act in a way that is not forbidden by law and nobody must be forced to act and do something that is not provided by law. Historically, this theory of social contract originated in the French revolution and since that time it has become the cornerstone of relations between citizens and state power. Moreover, it demonstrates the state character and the mode et forma of the individual parts of state power in the most significant and pronounced way. Administrative procedures are regulated by similar principles to those governing legal proceedings. Public administration bodies must take decisions within the confines of law, but they are obliged to respect the fundamental rights and freedoms affirmed by the Second Chapter of the Slovak Constitution. According to Article 152(2), everybody must interpret and administer constitutional acts, laws and other generally binding legal provisions in order to be in compliance with the Constitution. What is more, the state must take into consideration the quality of the personnel of every state and public administration body where not everybody has adequate legal education and therefore they must be under judicial control.

On the other hand, state and public administrators of the aforementioned public administration bodies are, or might be, specialists with a wide range of knowledge as regards a given problem area; nevertheless,

1 JUDr. Júlia Ondrová, PhD., P.A., Department of the Constitutional Law, Faculty of Law, Matej Bel University in Banská Bystrica, Slovak Republic. 
the reason for entrusting the judicial review of the administrative procedures to others is justified. The review by judges of regional courts who are more experienced than district court judges is not only reasonable but it meets the demands of the rule of law that the judicial review must be done in both instances. Not less important is the fact that public administrative bodies might violate law, therefore each lawful state must legally affirm the responsibility for the damage caused by public authority in its actions, and in principle this responsibility must be objective.

In the 1960s, a qualitative change started regarding the organisation of modern society. Even in that period the opinion appeared that the technical progress had led to the fourth industrial revolution has ${ }^{2}$. Since that time, those new conditions have been accompanied by many challenges and demands concerning the execution of public administration capacities. The most dominant feature of post-modern society is the emergence of particular interests which show the tendency to prevail over common interests ${ }^{3}$. Post-modern society brings with it not only crises of institutions but state and legal changes which are already evident in the state apparatus system. The state is gradually losing its power to act marked by erosion of the modern state and transferring its functions. The modern state is probably coming to its extinction, but not the state in its general sense; a new category has gradually appeared and that is the concept of the "open state" associated with public law emancipation and the state $e^{4}$. This postmodern situation constitutes a serious motivation for a reform of public power organisation which has a constant impact on the tripartite division of power.

\section{Introductory provisions of the Constitution}

The legal constitutional foundation of the Slovak Republic state system is defined by Article 1(1) of the Slovak Constitution pursuant to which the Slovak Republic is a sovereign, democratic state governed by the rule of law and thus safeguarding three fundamental self-governing qualities of the state on the territory of the Slovak Republic ${ }^{5}$. This provision creates the unchangeable "material" core of the Constitution. Any change or abolition of the aforementioned provision might in its essence cause a change of the state system.

2 Industry 4.0, https://en.wikipedia.org/wiki/Industry_4.0.

3 E. Barány, Power and Law, Bratislava: Veda 1997, p. 101.

4 P. Holländer, Dusk of the Modern State [in:] 20 years of the Constitution of the Slovak Republic - I. Constitution Days, vol. I, L. Orosz, M. Breichová Lapčáková, T. Majerčák (eds.), Košice: Pavel Jozef Šafárik University in Košice 2012, p. 59.

5 J. Drgonec, The Constitution of the Slovak Republic. Theory and Practice, Bratislava: C. H. Beck 2015, p. 194. 
Besides other things, the material core of the lawful state is built on the citizens' confidence in law and the legal order as defined by Article 1(1) of the Constitution. The precondition of such confidence includes the stability of the legal order and a satisfactory level of the citizens' legal trust. The stability of the legal order and legal certainty is not influenced only by the states legislative activities, such as the creation of law, but also by activities of the state bodies administering law. First of all, it includes the interpretation of the legal norm and then its administering, which considerably influences the creation of public awareness and people's perception of what is law and what is not (I. ÚS 665/2013).

Sovereignty is a constitutionally guaranteed characteristic of the Slovak Republic. It is understood as independence of the state power in relation to any other supremacy both in the area of international and domestic relations ${ }^{6}$. By means of its sovereignty, the state is entitled to decide autonomously on matters regarding its own territory, population, constitutional arrangement and the tripartite power division. However, each power must be restricted by the constitutional requirements of the democratic principle and the rule of law which generates prerequisites and limits of the public execution of state power. One of the pre-conditions of the democratic and rule-of-law state founded on the principle of people's sovereignty stated in Article 2(1) of the Constitution guarantees that the people-public-state power can be executed exclusively on the basis of democratic legitimacy, which consequently means that the state power which comes from the people might be executed either by their elected representatives or directly by the people ${ }^{7}$.

In order to prevent the usurpation of power, democracy as the fundamental quality of the state rests on the inevitability of re-establishing power by means of regular elections which must be held repeatedly and under the condition of preserving political plurality. Elections stand for a mechanism where citizens choose their representatives for the Parliament, and other representative bodies ${ }^{8}$.

The requirement of the democratic state presupposes the arrangement of public power bodies, their operational regime in relation to external actors and at the same time it regulates the mutual relations among individual public power bodies established by the Slovak Republic and the arrangement within each public power body as well'. As regards the power division, the Constitutional Court of the Slovak Republic has already pronounced

6 J. Klučka, International Law and the Constitution of the Slovak Republic, Košice: Medes 1996, p. 10-11.

7 I. CC 238/04, Finding of the Constitutional Court of the Slovak Republic of 31 January 2005.

8 P. Holländer, Foundations of the General Politics. 3. Publication, Plzeň: Aleš Čeněk 2012, p. 364.

9 J. Drgonec, The Constitution of the Slovak Republic..., p. 21. 
(PL.CC 16/95) that in a state ruled bylaw the competences, rights, obligations and regulations of state bodies amended by law, including legal and natural persons, create the necessary precondition to keep constitutional balance. Moreover, the system of power-division into the legislative, executive and judicial power is its inseparable part. In parliamentary democracy, they are all autonomous and mutually interconnected merely by constitutional control and cooperation.

It is evident from the constitutional balance principle that even the legislator cannot freely dispose of the individual parts of state power ${ }^{10}$. It is mainly the idea of a lawful state that creates the backbone and moral fibre of the whole legal order of the Slovak Republic. It is predominantly created by the principle of human rights and freedoms guarantees, the principle of legality and legitimacy, the principle of people's sovereignty, the principle of power division and the system of mutual checks and balances together with the principle of the Constitution and law sovereignty, and finally the principle of legal certainty ${ }^{11}$.

Another important provision of the Slovak Republic Constitution, which provides the basis for decision-making processes in public administration, is implemented by Article 2(2). Pursuant to this Article, the state bodies can only act in accordance with the Constitution, within its limits and scope as it is stated by law. One of the most basic principles of the functionally legal and consistent state and addressed to the state bodies is "What is not forbidden is allowed". The purpose of this principle is to safeguard the legal protection resting on the fact that public authorities will not act in contradiction of their powers. At the same time, it preserves legal safety securing which bodies of public authority are eligible to act with the subject of civil law. Pursuant to Article 23), subjects of civil law might use the contrarian principle. They can act within the sense that what is not forbidden by law may be done, and at the same time they must not be forced to do something that is not stated by law.

Given the fact that until 1918 the contemporary territory of the Slovak Republic had been an integral part of Austria-Hungary formed by many nationalities and ethnicities and that it was bound by international commitments, the Slovak Constitution has created an officially recognised opportunity for the National Council of the Slovak Republic to insert into the Constitution Article 6(2) affirming by law the opportunity to use other languages in official communication. The Act No. 184/1999 Coll. on the use of minority languages, as amended, allows the use of other languages as state languages only under the condition that they are used by national minorities. The use of the language of an ethnic group in official

10 PL. CC 25/00, Finding of the Constitutional Court of the Slovak Republic of 17 January 2002.

11 A. Bröstl et al., Theory of Law, Plzeň: Aleš Čeněk 2013, p. 171. 
communication is not allowed. In cases when a person declares that he/she is not able to understand the Slovak language as regards actions by state or public administration bodies, he/she has the right to use the service of an interpreter.

\section{The right to wardship and other legal protection}

The most important provision of the Slovak Constitution are contained in Article 46(1) and Article 46(2), pursuant to which everybody can claim his/her right to an independent and impartial court or to claim this right at another body of the Slovak Republic being eligible to act in a manner laid down by law. Anyone, who claims that he/she has been deprived of his/her rights by a decision made by a public administration body may turn to the court to have the lawfulness of such decision reviewed unless it is not laid down in a different way by law. However, the reviewed decision concerning fundamental human rights and freedoms must not be excluded from court competences.

Article 46(1) of the Slovak Constitution is the prime constitutional basis concerning the legally adjusted judicial proceedings applied by courts and other Slovak Republic bodies entitled to provide legal protection. At the same time, the Article marks a constitutional amendment concerning individual legal aspects regarding wardship and other judicial protection affirmed by Articles 46-50 of the Constitution. The general courts and the Constitutional Court provide that protection as it stated in Article 46(1) of the Constitution. Following this Article, they are bound by provisions of procedural and substantive law as respecting them creates the guarantee of the right to wardship (I. US 4/94). It means that they can act on the basis of the Slovak Republic's legal order and in this context the Slovak Republic Constitutional Court has pointed out that they are obliged to make decisions within the interest and under the authority of the norms of the Slovak Republic's Legal Order, or following such legal norms whose use is allowed by it.

The scope of duties of state bodies towards the subjects to whom the right to wardship or any other legal protection applies is adjusted by Article 2(2) of the Slovak Constitution. Each action provided by a public authority which is not in accordance with law, i.e. when a state body does not act within the limits and in a manner laid down by law, is in contradiction of the constitutional norm. If a court or any other body acts otherwise, as laid down in Article 46(1) of the Constitution regarding cases of claiming somebody's rights, they infringe on the right to wardship or any other legal protection guaranteed by the Constitution.

According to the Constitution, everyone is entitled to enjoy the right to wardship and any other legal protection as stated by the Legal Order of the 
Slovak Republic. It is affirmed that everybody can claim his/her rights in a court or any other body of the Slovak Republic as laid down by law. As regards proceedings before public administration bodies, not every right included in these provisions falls within their competence, e. g. pursuant to Article 48(1), no one can be deprived of an assigned judge. In this way, the right to a judge is declared as a right to be assigned to a representative of the judicial power. Pursuant to the seventh part of second Chapter of the Slovak Constitution, only those rights can be claimed before public administration bodies whose purpose is not entirely connected with the judicial power or criminal proceedings (II. CC 62/1999).

By a legal judgment of the Constitutional Court and Article 46(1), the basis of the fundamental right to other legal protection is executed by the fact that the eligible person may claim it in a manner laid down by law at a body competent to examine his/her claim. The range and duration of the validity to claim depend completely on the person who lodges a complaint. The precondition of its validity is met by fulfilling necessary conditions given by law as provided in Article 46(1) and Article 51 of the Slovak Constitution. Based on the facts stated in Article 46(1) of the Slovak Constitution, the fundamental right to other legal protection is infringed only in that case and in a such scope as is claimed by the freely acting eligible person before a body competent to examine his/her complaint regarding the right to other legal protection. In case the eligible person does not claim his/her basic right as regards other legal protection before a competent authority, it might be due to the fact that the right to protection he/she claims is subjected to judicial protection, or it might be caused by any other reasons, then the failing to act cannot be considered to be a violation of the basic right as it is affirmed by Article 46(1) of the Slovak Constitution.

In its essence, the provision of Article 46(2) adjusts the right of access to court as lex specialis, of access to court concerning the matter in question decided by a public administration body ${ }^{12}$. The right to review a judgment passed by a public administration body refers to administration justice. A special judicial system has been created by the Constitution anchoring the administrative justice. The purpose of Article 46(2) of the Slovak Constitution is to guarantee access to court for everybody who claims a violation of his/her rights by a decision issued by a public administration body. Access to court is not guaranteed whenever, only ad tunc et ibidem as is stated by law. Pursuing a claim to the right guaranteed by Article 46(2) of the Slovak Constitution is enforced by law (II. ÚS 12/97). Until entering into force of the new procedural code, Act No. 162/2015 Coll. the Code of Administrative Procedure, the examination of decisions made by general courts was included in the fifth part of the Code of Civil Procedure. As part of the recodification of procedural civil law, the approval of the procedural

12 J. Drgonec, The Constitution of the Slovak Republic..., p. 873. 
code seemed inevitable as it was mainly disturbed by the constantly spreading competences of administrative judiciary bodies. Article 46(2) expresses the basic principle on which the single Act has been based. Provision of Article 2(2) of the Act specifies the prospect and right for everybody claiming an infringement of his/her rights caused by a decision made by a public administration body, to address an administrative court under the conditions stated by this Act. In the meaning of its Article 5(2), the procedure at the administrative court is considered one of the guarantees as regards the protection of fundamental human rights and freedoms and the justified interests of the parties to administrative proceedings.

The second sentence of the quoted Article guarantees the right of access to court in relation to the examination of every decision made by every public administration body, if the decision concerns a certain basic right or freedom. Regarding the second sentence of the Article 46(2), the Constitution Court of the Slovak Republic has noted that the quoted constitutional norm does not in any case and in any way determine the type of judicial procedure or on what type of motion courts have to review such decisions. Further, the decisions which should be from one reason or another excluded from the judicial review are not mentioned, either. The only intention taken into consideration is basic rights or fundamental freedoms. Therefore, if a judgment delivered by the administrative body concerns a fundamental right or freedom, meaning any kind of basic right or freedom, it must not be excluded from the judicial power of courts ${ }^{13}$, the exclusion of such a judgment might be considered to be a violation of the basic right affirmed by Article 46(2) of the Slovak Constitution.

\section{Right to compensation for damage caused by an unlawful decision or incorrect official procedure applied by a public authority}

Courts, as well as other state and public administration bodies are not artificial entities. In spite of spreading smart artificial intelligence, their personal substance is made of human beings. Due to the fact that a human being is a creature who is fallible and makes mistakes, and as the state is aware of this reality, the Slovak Republic as a modern and democratic state has decided to anchor the so-called court's objective responsibility regarding other state and public administration bodies concerning the damage caused by their unlawful decisions or by incorrect official procedures.

As a consequence of this reality, two interrelated and mutually independent rights have been constituted by Article 46(3) of the Constitution yet their idea is the same and the idea behind them is to avoid apparent slipups.

13 II. ÚS 50/2001, Finding of the Slovak Republic Constitutional Court of 11 October 2001. 
The purpose of the basic right to compensation for damage caused by an unlawful judgment or an incorrect official procedure of a public authority is not to provide a satisfaction for every subject in relation to whom some public body violated his/her fundamental right conferred by the Legal Order of the Slovak Republic. Both basic rights conferred by the quoted Article of the Slovak Constitution are defined in relation to the damage caused ${ }^{14}$. It means that if the damage has been caused to somebody in the aforementioned procedure or judgment, the right to compensation for the damage arises for this subject. However, not every unlawful outcome is compensated for; of course, it does not preclude another type of responsibility that might arise in connection with a procedure or action considered incorrect or unlawful under another Act.

In the same way, as it is stated in any other legal provisions regarding responsibility for an unlawful action, the Slovak Constitution wants to force into effect preventive measures influencing the courts, other state bodies and public administration bodies by the attachment of the abovementioned rights. All employees of public authorities must be aware that they can act only on the basis of the Constitution, within its limits and scope, and in the manner laid down by law as is affirmed by Article 2(2) of the Slovak Constitution. What is more, a public authority, in the name of which a certain individual acts, may bear the full responsibility and accountability for the damage caused as a result of a wrong official procedure. In addition to Act No. 514/2003 on responsibility for the damage caused concerning the execution of public authority, as amended, adjusts the right of public bodies to counteraction to persons who share their responsibility regarding the delivery of a definite decision or causing an incorrect official procedure. The Act on responsibility for the damage caused committed by an act of public authority is, according to the stance of the Supreme Court of the Slovak Republic ${ }^{15}$, a special case of responsibility for damage which constitutes an exception from the general clause on general responsibility for damage affirmed by Article 420 of the Civil Code. According to the aforementioned Act, fulfilled are all preconditions for responsibility for damage to arise.

Those rights are not of absolute nature. Pursuant to Article 51(1) of the Slovak Constitution, they might be claimed only within the scope of laws laid down by their provisions. The precondition for the entitlement to seek responsibility for the damage caused by an unlawful decision creates the foundation for issuing a legally valid judgment, and consequently an option for the abolishment of the previous legitimate ruling; however, we have to add that this right is limited. The aforementioned law on responsibility for the damage caused adjusts reasons but excludes the existence of the

14 J. Drgonec, The Constitution of the Slovak Republic..., p. 881.

154 Cdo 357/2012, Decision of the Supreme Court of the Slovak Republic of 20 December 2012. 
basic right to compensation for damage. It mainly pertains to cases where the damage was caused by the subject himself/herself or, a justified legal remedy has not been applied for at all by the subject even when he/she has this right. However, on the other hand, the legal remedy must be an effective legal instrument mainly as regards criminal proceedings. The reason for it is related to the fact that a claim against a ruling on indictment seems to be rather an illusory legal remedy since when deciding about a claim, the prosecution takes into consideration the same outcomes of the existing investigation conducted by an investigator or entitled member of the police. Criminal authorities leave a space for them acting, and consequently for defending their activities. It is evident in many cases that without any selfreflection, the prosecution takes legal steps and so transfers its responsibility for the pre-trial decision to the court.

However, in criminal proceedings responsibility for damage might appear as well, especially if in the first instance a criminal justice authority brings a suit which the accused questions and as a consequence the appeal is turned down by the prosecution, but thereafter a result of the pre-trial proceedings the prosecution comes to the conclusion that it is necessary to bring the criminal prosecution to an end. The fault of the Criminal Code rests in the fact that the prosecution does not overturns the court ruling on the exoneration from a charge but stops the criminal prosecution of a certain person or towards a certain person and the subject-matter in question. The body in question regarding the examination of a claim to compensation for damage argued that the court ruling had not been formally closed but settled down only by the decision-making of general courts (4 M Cdo 15/2009). It is evident that the right interpretation of this provision must not be presented only being based of the language interpretation, de verbo in verbum interpretation of the grammatical commentary, but on the other hand it is necessary to apply a systematic and teleological explanation and interpretation.

From the systematic point of view of related to the explanation of legal standard content based on the mutual relations with other legal norms, we might come to the following conclusion; while the cited provisions of Article 18(1) of the Act on responsibility and accountability for the damage caused is found in the fourth part labelled as common provisions, its practical implication can be considered in relation with other norms regarding procedural costs, the costs incurred during the proceedings when the case was deferred to another authority, even to cover the expenses in case when the state is responsible for the damage caused by an unlawful decision as is affirmed by Article 6 of the Act in question. From the teleological point of view based on the meaning and intention of legal regulation which in the case of this Act stands for the protection of the basic right to remedy for damage caused by an unlawful decision or incorrect official procedure 
pursuant to Article 46(3) of the Slovak Constitution, it is impossible to adhere to the formal annulment of the affirmed unlawful decision but it is necessary to interpret this condition extensively.

Only such an explanation is considered to be in conformity with the Constitution, if in the case of assessing the state's responsibility for the damage caused by the decision on starting criminal prosecution and bringing a charge criminal charge prosecution is brought to a stop when that decision was made because of non-fulfilment of the assumption on the committal of a criminal act by the suspect, it has the same consequences as the overturning of a ruling to start criminal prosecution with a view of pursuing a charge caused by lawlessness. By the res iudicata on the suspension of criminal prosecution the criminal proceeding is ended; it means that the effects of the decision to institute criminal prosecution and bringing a charge cease to exist. Moreover, suspension of the criminal proceeding means that the outcomes of criminal, pre-trial proceedings signify that it was not a criminal act and at the same time it means that the suspicion of committing a criminal act was not confirmed and as a result the unlawfulness of the decision to institute a prosecution on criminal charge was evident.

In case of criminal prosecution which was suspended, the Constitution and legal basis regarding an individual claim to compensation for damage is found not only in the Article 46(5) of the Slovak Constitution but in the general conception, mainly in Article 1(1) of this fundamental law which connotes the principles of the material rule of law. If a state has to be considered as to be a state ruled by law, it must bear objective responsibility for actions of its bodies by which fundamental individual rights were persistently affected. It cannot be overlooked that the state has no free will but it must strictly observe the law in its ideal interpretation in order not to cause damage. On one hand, it is a duty of the bodies responsible for taking legal steps against criminal acts to investigate and prosecute criminal activity, but on the other hand the state cannot lift its responsibility for the procedures of those bodies when it is evident that their course of action appears to be erroneous, infringing on basic rights. In such a situation, it is not decisive how the bodies active in criminal procedure evaluate the original suspicion but the fact whether their suspicion was affirmed by criminal procedure (4 M Cdo 15/2009).

The assumption of responsibility for damage caused by an incorrect official proceeding is expressed by the requirement that such proceeding must be official and wrong. In the context of the proceeding, judicial practice includes not only the proceeding itself but failing to act as well, consisting in inactivity or failure to notice. The official proceeding covers the personal activities that fulfil tasks and obligations given by the state bodies and under the condition when this proceeding serves the execution 
of state authority (4 Cdo 24/2). The Act on responsibility for damage caused does not define what an incorrect official procedure means Argumentum a contrario; if a correct official procedure is in congruence with the provision of Article 2(2) of the Slovak Constitution, then an incorrect official proceeding might consist in a procedure of a public administration body without competences, or in the implementation of powers which are beyond the scope of law, or under conditions and mode which are not in compliance with the law, or if this body does not discharge its duties related to its given powers, or if they violate a person's justified right having a connection with a certain public administration body.

\section{Conclusion}

The public administration decision-making processes represent the most essential component of the legal proceedings going on in the Slovak Republic. Often, these legal procedures are or might have been of significant meaning for the status of private persons, their privacy, their personal and family lives, the social and economic rights, and so forth.

Therefore, this reality has motivated the author to try to identify and analyse the constitution and legal foundations of the legal provisions regulating administrative procedures. The aim of the article presented is to point out to relevant Articles of the Slovak Constitution serving as the wide-spread basis for the decision-making processes applied by the public administration bodies. The analytical method has been mostly used by the author when dealing with the Constitution and legal amendments and when examining the decision-making activities of the Slovak Republic's Constitution Court and Supreme Court. Besides that. the centre of her attention was analysis of scholarly academic literature concerning the research topic; the list of the publications analysed can be found at the end of the article.

By analysing individual provisions of the Constitution, the author tried not only to examine them but also to evaluate the wide spectrum of the provisions of individual Articles anchored by the first part, i.e. the first Chapter of the Slovak Constitution. Their influence on the decision-making processes applied by public administration bodies was examined as well. Accordingly, the author focused her attention on individual constitutional rights being affirmed by the seventh part of the second Chapter of the Slovak Constitution regulating the right to wardship and other legal protection. By analysing academic literature of the subject, the author has come to the conclusion that the theory of the tripartite division of state power has started to become slightly outdated in the post-modern state, finding its reflection also in state management, which is gradually becoming more and more complicated, especially in the field of public administration. 
Economic, sociological, cultural, technical and other developments in society have a significant impact not only on the structure of public administration bodies but on their decision-making processes, too. In spite of such developments, the Constitution and legal adjustments amending the decision-making processes are quite satisfactory and according to some authors, when interpreting the Constitution of the Slovak Republic we have to abandon the method of historical explanation and the legal custom and usage as they consider these tools of interpretation to be the most dangerous, creating a deeper gap between the status of society and the attempts to Its solution by applying the Constitution.

\section{Bibliography}

Bárány E., Power and Law, Bratislava: Veda 1997.

Bröstl A. et al., Theory of Law, Plzeň: Aleš Čeněk 2013.

Drgonec J., The Constitution of the Slovak Republic. Theory and Practice, Bratislava: C. H. Beck 2015.

Holländer P., Foundations of the General Politics, 3rd Edition, Plzeň: Aleš Čeněk 2012.

Holländer P., Dusk of the Modern State [in:] 20 years of the Constitution of the Slovak Republic - I. Constitution Days, vol. I, L. Orosz, M. Breichová Lapčáková, T. Majerčák (eds.), Košice: Pavel Jozef Šafárik University in Košice 2012.

Klučka J., International Law and the Constitution of the Slovak Republic, Košice: Medes 1996.

Wagnerová E., Šimíček V., Langásek T., Pospíšil I. et al., The Bill of Fundamental Rights and Freedoms. Commentary, Prague: Wolters Kluwer, Czech Republic, a.s. 2012.

Abstract

The subject-matter of the article is the identification and analysis of the constitutional foundations of the legal provisions regulating the administrative procedure of public administration bodies in the Slovak Republic and analysis of decisions made by the Slovak Constitutional Court and Supreme Court. The administrative procedure represents an immanent process in which state and public administration bodies make decisions on rights, legitimate interests as well as obligations and duties in the field of state and public administration. The author aims to identify the most important provisions of the Slovak Constitution and to demonstrate their significance for the decision-making activities of domestic public administration bodies and at the same time to find out if the constitutional and legal basis is sufficient enough to make amendments regarding the decision-making processes of Slovak public administration bodies. The author's research hypothesis, resting on an enquiry to identify if the constitutional amendment is satisfactory and acceptable, is followed by an investigation of mutual relations between the current state of our society and its conditions being in a state of its rapid development and the contents of the constitutional amendment. It is argued that the 
Constitution as the basic piece of legislation must be adopted with accepted text so that potential changes would not entail having to change the Constitution.

Keywords: Slovak Republic, post-modern state, Constitution, public administration, rule-of-law state, administrative process, public administration bodies, legal right, protection

\section{Podstawa konstytucyjna i prawna procesów decyzyjnych stosowanych przez organy administracji publicznej w Republice Słowackiej}

Streszczenie

Przedmiotem artykułu jest zidentyfikowanie oraz analiza podstaw konstytucyjnych przepisów prawnych regulujących postępowanie administracyjne przed organami administracji publicznej w Republice Słowackiej, jak też analiza decyzji wydawanych przez słowacki Trybunał Konstytucyjny i Sąd Najwyższy. Procedura administracyjna stanowi immanentny proces, w którym organy państwa i administracji publicznej podejmują decyzje dotyczące praw, uzasadnionych interesów oraz zobowiązań i obowiązków w obszarze państwa i administracji publicznej. Autorka zmierza do ustalenia najistotniejszych przepisów słowackiej konstytucji oraz wykazania ich znaczenia dla działań decyzyjnych krajowych organów administracji publicznej, a jednocześnie dowiedzenia się, czy istnieje wystarczająca podstawa konstytucyjna i prawna do nowelizacji prawa w zakresie procesów decyzyjnych stosowanych przez słowackie organy administracji publicznej. Po określeniu hipotezy badawczej, zasadzającej się na próbie sprawdzenia, czy nowelizacja konstytucji jest konieczna i akceptowalna, następuje badanie wzajemnych relacji pomiędzy obecnym stanem społeczeństwa i jego warunków znajdujących się w stanie raptownych zmian oraz treścią nowelizacji konstytucji. Autorka twierdzi, iż jako ustawa zasadnicza konstytucja musi zawierać treści powszechnie akceptowane tak, by potencjalne zmiany nie musiały prowadzić do zmiany konstytucji.

Słowa kluczowe: Republika Słowacka, państwo ponowoczesne, konstytucja, administracja publiczna, państwo prawa, proces administracyjny, organy administracji publicznej, legalne prawo, ochrona 